\title{
Bioavailabilitas $\alpha$-Tokoferol Minuman Emulsi Minyak Sawit dalam Plasma Darah dan Hati Tikus (Rattus norvegicus)
}

\author{
Bioavailability of $\alpha$-Tocopherol in Palm Oil Emulsion Drink on Rats (Rattus norvegicus) Blood Plasma and Liver \\ Winda Christina Harlen ${ }^{1 *}$, Tien Muchtadi ${ }^{1,2}$, Nurheni Sri Palupi ${ }^{1}$ \\ ${ }^{1}$ Departemen Ilmu dan Teknologi Pangan, Fakultas Teknologi Pertanian, Institut Pertanian Bogor, \\ Kampus IPB Dramaga,Bogor 16002, Indonesia \\ ${ }^{2}$ Southeast Asian Food and Agricultural Science and Technology (SEAFAST) Center, \\ Institut Pertanian Bogor, Kampus IPB Dramaga, Bogor 16002, Indonesia \\ Email: wind.harlen@gmail.com
}

Submisi: 29 Juni 2016; Penerimaan: 10 Mei 2017

\begin{abstract}
ABSTRAK
Minuman emulsi minyak sawit (MEMS) merupakan salah produk berbasis emulsi oil-in-water yang dapat menjadi sumber vitamin E dalam bentuk $\alpha$-tokoferol. Komposisi dasarnya adalah olein minyak sawit, air, dan pengemulsi. Secara teoritis, produk ini kaya akan $\alpha$-tokoferol namun bioavailabilitasnya belum diketahui. Oleh karena itu, tujuan penelitian ini adalah (1) Menganalisis komposisi kimia MEMS melalui uji proksimat dan kadar $\alpha$-tokoferolnya, dan (2) Mengevaluasi bagaimana bioavailabilitas $\alpha$-tokoferol secara in vivo. Evaluasi bioavailabilitas dengan memperhitungkan Tocopherol Accumulation Factor (TAF) relatif, sedangkan komposisi kimia didapatkan melalui analisis proksimat dan kromatografi dengan HPLC untuk mengetahui kadar $\alpha$-tokoferol. Kadar $\alpha$-tokoferol yang didapatkan sebesar 192,63 $\mu g / g$. Pengujian biovailabilitas dilakukan selama 14 hari menggunakan hewan coba berupa tikus Rattus norvegicus. Ransum yang diberikan mengandung $30 \mathrm{mg} / \mathrm{kg} \alpha$-tokoferol. Nilai TAF sebesar 1/45,61, yang berarti bahwa 45,61 $\mu \mathrm{g}$ vitamin E dari MEMS dapat menghasilkan $1 \mu \mathrm{g}$ tokoferol hati. Bioavailabilitas relatif $\alpha$-tokoferol pada MEMS terhadap $\alpha$-tokoferol murni sebesar $82,46 \%$. Hasil tersebut menunjukkan bahwa MEMS memiliki bioavailabilitas yang baik.
\end{abstract}

Kata kunci: $\alpha$-tokoferol; bioavailabilitas; minyak sawit; minuman emulsi minyak sawit; Tocopherol Accumulation Factor

\begin{abstract}
Palm oil emulsion drink (POED) is a kind of oil-in-water emulsion which consider to be a good source of $\alpha$-tocopherol. The POED consists of palm olein, water, and emulsifier. Theoritically, it should contains high amount of $\alpha$-tocopherol but its bioavailability have not been studied yet. The aim of this research were (1) to review the chemical composition of POED by doing proximate test then calculate $\alpha$-tocopherol level in the product and (2) to evaluate bioavailability of $\alpha$-tocopherol based on in vivo study. Bioavailability evaluation was carried out by measuring Relative Tocopherol Accumulation Factor (TAF), meanwhile its chemical composition was measured by proximate test and chromatographic analysis using HPLC. $\alpha$-tocopherol contents of this products were $192,63 \mu \mathrm{g} / \mathrm{g}$. Bioavailability study was carried out for 14 days using Rattus norvegicus rats. The prepared food contains $30 \mathrm{mg} / \mathrm{kg} \alpha$-tocopherol were given to vitaminE-depleted rats. Tocopherol Accumulation Factor (TAF) proposed for the test group is $1 / 45,61$, which indicated that $45,61 \mu \mathrm{g}$ vitamin $\mathrm{E}$ from this product was needed to accumulate $1 \mu \mathrm{g}$ tocopherol in the liver. Tocopherol relative bioavailability of POED was $82,46 \%$. It showed that POED has good bioavailability.
\end{abstract}

Keywords: $\alpha$-Tocopherol; bioavailability; palm oil; palm oil emulsion drink; Tocopherol Accumulation Factor 


\section{PENDAHULUAN}

Minyak sawit merupakan salah satu minyak nabati yang memiliki banyak keunggulan jika dilihat dari mutu gizinya. Selain mengandung asam lemak tak jenuh seperti asam oleat $(39,2 \%)$, asam linoleat $(10,1 \%)$, dan asam alfa linolenat $(0,4 \%)$, minyak sawit juga mengandung komponen bioaktif seperti $\beta$-karoten, tokotrienol, dan tokoferol (Mancini dkk., 2015). Keberadaan $\beta$-karoten dalam minyak sawit sebagai salah satu karotenoid paling aktif telah banyak dikaji manfaatnya. Namun pengkajian mengenai tokotrienol dan tokoferol dalam minyak sawit belum banyak dilakukan.

Tokoferol dan tokotrienol adalah golongan vitamin E yang berasal dari tumbuhan. Salah satu jenis tokoferol aktif yang mampu diserap oleh tubuh manusia adalah $\alpha$-tokoferol. Tokoferol merupakan bentuk vitamin $\mathrm{E}$ yang paling sering berada dalam sistem sirkulasi (Ball, 2006). Alfa-tokoferol merupakan golongan vitamin $\mathrm{E}$ yang berperan dalam ekspresi gen dan homeostasis sel (Li dkk., 2010). Vitamin E dapat berfungsi sebagai antioksidan sehingga dapat mencegah berbagai penyakit degeneratif. Sebagai antioksidan, vitamin E berperan pada regulasi sinyal seluler, proliferasi sel, ekspresi gen, serta memicu radikal peroksil lipid dengan menyumbangkan atom hidrogen pada Reactive Oxygen Species atau ROS (Devaraj dkk., 2007).

Metabolisme $\alpha$-tokoferol sebagai vitamin E bergabung dengan metabolisme lemak. Vitamin E membutuhkan asam empedu dan enzim-enzim pankreas untuk membentuk misel sehingga bisa diserap oleh sel epitel usus. Setelah itu, vitamin E digabungkan dengan kilomikron kemudian dibawa ke sistem limfatik dan ke sirkulasi darah. Absorbsi vitamin E di usus diatur oleh scavenger receptor kelas B tipe 1 (SRB1) dengan mekanisme mirip dengan penyerapan kolesterol (Gagne dkk., 2009). Vitamin E paling banyak diserap di enterosit dan masuk ke sirkulasi tubuh melalui sistem limfatik, lalu diabsorbsi bersama lipid melalui kilomikron (Ball, 2006). Ketika memasuki sirkulasi darah kilomikron akan mengalami lisis karena enzim lipoprotein lipase dan membentuk kilomikron remnant. Akibat lipolisis tersebut vitamin E akan ditransfer ke High Density Lipoprotein (HDL) untuk dibawa ke sistem sirkulasi. Proses transfer tersebut akan dipercepat oleh protein transfer fosfolipid. Sisa vitamin E dalam kilomikron remnant yang tidak digunakan dibawa ke hati oleh sel parenkim untuk kemudian disimpan sebagai cadangan vitamin E (Gee, 2011). Ketika tubuh memerlukan vitamin $\mathrm{E}$, hati akan mensekresi $\alpha$-tokoferol ke plasma melalui Very Low Density Lipoprotein (VLDL).

Alfa-tokoferol memiliki sifat tidak stabil terhadap oksidasi dan pengolahan suhu tinggi. Kandungan tokoferol bisa berkurang selama pengolahan, penyimpanan, dan penggunaan dalam produk pangan tertentu (Ball, 2006). Alfa-tokoferol bersifat sangat lipofilik sehingga harus didispersikan dalam fase larut lemak dan tidak bisa secara langsung didispersikan ke dalam fase larut air. Sebagaimana jenis vitamin E yang lain, $\alpha$-tokoferol juga mengalami penyerapan di usus halus dalam wujud misel berupa campuran asam empedu dan hasil sekresi pankreas. Peningkatan absorbsi $\alpha$-tokoferol umumnya ditandai oleh peningkatan jumlah misel tersebut (Yang dan McClements, 2013).

Bioavailabilitas $\alpha$-tokoferol dipengaruhi salah satunya oleh keberadaan lemak. Hal ini dikarenakan vitamin tersebut larut lemak dan membutuhkan kilomikron sebagai media transportasi dalam tubuh (McClements dkk., 2016). Minuman emulsi minyak sawit (MEMS) sebagai salah satu produk hasil pengolahan dari minyak sawit diharapkan dapat menjadi sumber vitamin $\mathrm{E}$ dalam bentuk $\alpha$-tokoferol. MEMS adalah hasil emulsi minyak dalam air (oil-in-water). Formula dasar pembuatan MEMS adalah air, minyak, dan emulsifier, sedangkan bahan lain seperti pengasam, pengawet, dan perisa dapat ditambahkan sesuai dengan hasil akhir yang diinginkan (Surfiana, 2002). Produk ini menjadi salah satu olahan minyak sawit yang diindikasikan dapat mempertahankan kandungan $\alpha$-tokoferol karena tidak mengalami proses pemanasan berlebihan selama pengolahan, yaitu tidak melebihi $110{ }^{\circ} \mathrm{C}$ sehingga tidak mengurangi kadar total vitamin $\mathrm{E}$ (Ball, 2006). Hal ini memungkinkan retensi $\alpha$-tokoferol pada MEMS dalam jumlah yang cukup banyak.

Secara teoritis, MEMS dapat menjadi sumber vitamin E. Namun, metabolisme dan aktivitas biologisnya di dalam tubuh perlu dikaji lebih lanjut karena penyerapan $\alpha$-tokoferol dalam tubuh dipengaruhi oleh banyak faktor fisiologis (McClements dkk., 2016). Oleh karena itu, tujuan dari penelitian ini adalah untuk menganalisis komposisi kimia MEMS melalui analisis proximat dan uji kadar $\alpha$-tokoferol serta menentukan bioavailabilitas $\alpha$-tokoferol secara in vivo.

\section{METODE PENELITIAN}

\section{Bahan dan Alat}

Bahan baku yang digunakan dalam pembuatan MEMS yaitu Crude Palm Oil (CPO) yang diperoleh dari PT Salim Ivomas Pratama Jakarta. Bahan tambahan pangan yang digunakan adalah kalium sorbat, butil hidroksi toluen (BHT), pengemulsi Tween-80, perisa melon, dan pemanis fruktosa. Sementara itu, bahan kimia yang digunakan untuk analisis adalah $\mathrm{H}_{2} \mathrm{SO}_{4}, \mathrm{NaOH}, \mathrm{NaCl}, \mathrm{CH}_{3} \mathrm{COOH}$ glasial, $\mathrm{KOH}, \mathrm{K}_{2} \mathrm{SO}_{4}, \mathrm{HgO}, \mathrm{H}_{3} \mathrm{BO}_{3}, \mathrm{HCl}, \mathrm{AgNO}_{3}$ metanol, $\mathrm{Na}_{2} \mathrm{SO}_{4}$ anhydrous, heksan, asam askorbat, dan isopropanol yang seluruhnya didapat dari Merck.

Pengujian bioavailabilitas meggunakan tikus Rattus norvegicus jantan galur Sprague dawley. Bahan yang 
digunakan untuk pembuatan ransum tikus adalah minuman emulsi minyak sawit (MEMS), kasein, selulosa, minyak jagung, tepung maizena, vitamin mix, mineral mix, dan aquades. Bahan kimia yang digunakan sebagai standar adalah $\alpha$-tocopherol (Sigma T-3251, $\geq 96 \%$ ).

Peralatan yang digunakan yaitu Neutralizer (SM 100Ne), Deodorizer (SM 100-Be), Homogenizer (Armfield Silverstone), peralatan bedah tikus, tabung EDTA, timbangan analitik(Sartorius model BSA224), dan sentrifus (Eppendorf). Analisis kadar tokoferol pada MEMS serta pada organ hati dan plasma darah tikus dilakukan menggunakan instrumen HPLC-UV Vis (Shimadzu C-R6A) kolom C18 (Zorbac Eclipse) dengan panjang kolom $150 \mathrm{~mm}$ dan diameter 4,6 mm untuk analisis tokoferol.

\section{Pembuatan Minuman Emulsi Minyak Sawit}

Formulasi pembuatan minuman emulsi minyak sawit (MEMS) mengikuti formula Surfiana (2002), seperti tertera dalam Gambar 1. Crude Palm Oil (CPO) diberi perlakuan pemurnian dan fraksinasi sehingga didapatkan fraksi cair (olein) dan fraksi padat (stearin). Bahan utama yang digunakan dalam pembuatan MEMS adalah olein. Rasio jumlah minyak dan air yang digunakan dalam pembuatan MEMS adalah 7:3.

\section{Analisis Komposisi Kimia Minuman Emulsi Minyak Sawit}

\section{Analisis proximat pada minuman emulsi minyak sawit}

Analisis proksimat yang dilakukan pada MEMS adalah analisis kadar protein dengan metode Kjeldahl (AOAC 2005), analisis kadar lemak dengan metode Sohxlet (BSN 2006), kadar air dan abu dengan metode gravimetri (AOAC 2005), dan kadar karbohidrat dengan metode by difference.

\section{Analisis Kadar $\alpha$-tokoferol pada minuman emulsi minyak sawit}

Analisis kadar $\alpha$-tokoferol menggunakan metode kromatografi. Instrumen yang digunakan adalah HPLC UVVIS (Shimadzu C-R6A) dengan kolom C18. Fase gerak yang digunakan adalah metanol dan isopropanol dengan perbandingan 98:2 pada flow rate $1 \mathrm{~mL} / \mathrm{menit}$. Panjang gelombang yang digunakan adalah $290 \mathrm{~nm}$.

Metode persiapan sampel mengikuti AOAC (2012) dengan modifikasi penambahan asam askorbat sebagai antioksidan. Sebanyak $1 \mathrm{~g}$ sampel ditimbang ke dalam tabung reaksi berpenutup dan dilakukan saponifikasi dengan menambahkan $4 \mathrm{~mL}$ alkohol, 0,3 g asam askorbat, dan $10 \mathrm{~mL}$ larutan $\mathrm{KOH} 5 \%$. Larutan tersebut dihembus dengan gas $\mathrm{N}_{2}$ teknis selama 30 detik. Selanjutnya dilakukan homogenasi dan pemanasan dengan water bath di suhu $65^{\circ} \mathrm{C}$ selama 30

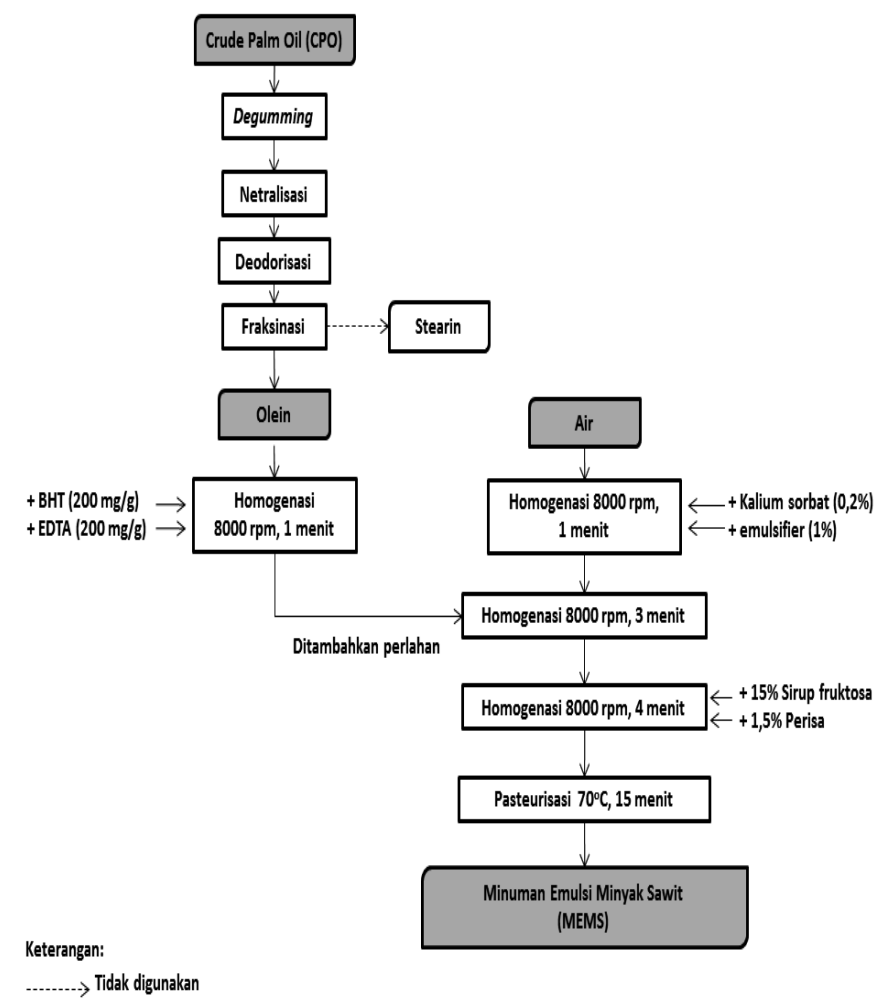

Gambar 1. Pembuatan minuman emulsi minyak sawit (Surfiana, 2002)

menit. Sampel kemudian diangkat dan didinginkan di bawah air mengalir lalu ditambahkan $20 \mathrm{~mL}$ air dan dihomogenasi selama 2 menit. Kemudian ditambahkan heksan sebanyak 10 $\mathrm{mL}$ ke dalam tabung reaksi. Larutan lalu didiamkan sampai terpisah menjadi dua fraksi. Fraksi tidak larut air di bagian atas diambil dengan pipet tetes dan dipindahkan ke tabung lain, sambil dilewatkan pada natrium sulfat anhydrous dalam kertas saring. Ekstraksi dilakukan sebanyak 3 kali, kemudian seluruh fraksi tidak larut air yang didapat diuapkan dengan gas $\mathrm{N}_{2}$ teknis sehingga diperoleh ekstrak $\alpha$-tokoferol. Setelah itu, eksktrak dilarutkan dengan 1,0 mL tepat fase gerak dan disaring dengan membran mikron $0,45 \mu \mathrm{m}$. Identifikasi peak $\alpha$-tokoferol dalam sampel dilakukan dengan mencocokkan waktu retensi standar $\alpha$-tokoferol murni dengan waktu retensi peak sampel. Cara perhitungan konsentrasi $\alpha$-tokoferol basis basah tersaji dalam Persamaan 1:

$$
\text { Standar }(\mathrm{mg}) \mathrm{x} \frac{\text { vol larutan sampel }(\mathrm{mL})}{100 \mathrm{~mL}} \times \text { Faktor Pengenceran }
$$

\section{Analisis Bioavailabilitas a-tokoferol Minuman Emulsi Minyak Sawit}

\section{Komposisi ransum hewan percobaan}

Terdapat 4 jenis ransum berbeda yang digunakan sesuai masa perlakuan dan kelompok perlakuan. Tipe ransum yang 
digunakan adalah ransum semi basah dengan komposisi ransum standar mengacu pada AOAC: 960.48 (2012). Ransum dan air minum diberikan secara ad libitum. Ransum kelompok kontrol adalah ransum standar (S). Ransum deplesi (D) memiliki komposisi yang sama dengan ransum standar namun diberikan pengurangan vitamin E. Ransum kontrol positif (KP) dan ransum minuman emulsi minyak sawit (MEMS) memiliki komposisi sama dengan ransum D namun ditambahkan $\alpha$-tokoferol murni sebesar $600 \mu \mathrm{g}$ $\alpha$-tokoferol/20 g ransum untuk kontrol positif, sedangkan pada ransum minuman emulsi ditambahkan MEMS sebesar $175,11 \mathrm{~g} / \mathrm{kg}$ ransum. Penambahan pada ransum KP dan ransum MEMS tersebut diperhitungkan untuk mendapatkan $30 \mathrm{mg} \alpha$-tokoferol/kg ransum yang terbukti efektif dalam mengembalikan cadangan tokoferol di hati (Hatanaka dkk., 2010).

\section{Perlakuan pada hewan percobaan}

Sebanyak 36 ekor tikus digunakan dalam penelitian ini. Total masa pemeliharaan adalah 84 hari, terdiri dari 10 hari masa adaptasi, 60 hari masa deplesi, dan 14 hari masa replesi. Semua tikus ditempatkan dalam kandang individu. Ransum diganti setiap hari dan ditimbang untuk mengetahui intake harian tikus. Perkembangan tikus dipantau melalui penimbangan berat badan setiap tiga hari sekali.

Pada masa adaptasi, semua tikus $(n=36)$ mendapat ransum yang sama, yaitu ransum standar (S). Di masa deplesi, kelompok kontrol $(n=6)$ tetap mendapat ransum $\mathrm{S}$, sedangkan kelompok deplesi $(\mathrm{n}=24)$ mendapat ransum deplesi (D) atau ransum kurang vitamin E. Pada masa replesi, kelompok yang sebelumnya merupakan kelompok deplesi dibagi menjadi 3 kelompok, yaitu kelompok kontrol positif (KP), kontrol negatif (KN), dan kelompok minuman emulsi minyak sawit (MEMS). Di masa replesi, kelompok kontrol (K) tetap mendapat ransum S. Sementara itu, kelompok KP $(n=6)$ mendapat ransum KP, sedangkan kelompok MEMS $(n=6)$ mendapat ransum MEMS. Kelompok KN $(n=6)$ tetap mendapat ransum D.

\section{Terminasi dan pembedahan hewan percobaan}

Pada akhir masa adaptasi dilakukan terminasi dan pembedahan terhadap 6 ekor tikus, sedangkan di masa deplesi dilakukan terminasi dan pembedahan 6 ekor tikus dari kelompok deplesi. Terminasi dan pembedahan juga dilakukan di akhir masa replesi pada 24 ekor tikus yang tersisa. Tujuan terminasi adalah untuk mengetahui status tokoferol plasma dan tokoferol hati. Terminasi dilakukan dengan metode cervical dislocation. Whole blood diambil menggunakan syringe ukuran $5 \mathrm{~mL}$ dan dimasukan ke dalam tabung vakum berisi antikoagulan EDTA kemudian disentrifus untuk memisahkan plasma dan serum menggunakan Sentrifus (Eppendorf) pada $3000 \mathrm{rpm}$ suhu $25^{\circ} \mathrm{C}$ selama 15 menit. Supernatan yang terbentuk kemudian diambil, dimasukan ke dalam microtube, dan disimpan pada suhu $-20^{\circ} \mathrm{C}$ sampai tiba masa persiapan sampel. Organ hati diambil dari tubuh dan dicuci dari darah menggunakan larutan $\mathrm{NaCl} 10 \%$. Lalu organ ditiriskan, ditimbang, dibekukan dengan $\mathrm{N}_{2}$ cair. Organ hati yang sudah beku kemudian dibungkus dengan alumunium foil, dimasukan ke dalam plastic box, dan disimpan dalam suhu $-20^{\circ} \mathrm{C}$.

\section{Analisis Kadar Tokoferol Plasma dan Tokoferol Hati}

Metode analisis sampel tokoferol plasma mengikuti Domitrovic dkk. (2008) dengan modifikasi fase gerak berupa metanol:isopropanol $=98: 2(\mathrm{v} / \mathrm{v})$. Sebanyak 0,5 ml plasma darah ditambah dengan $0,5 \mathrm{~mL}$ etanol dan dihomogenkan. Setelah itu ditambahkan $4 \mathrm{~mL}$ heksan dan divorteks hingga terbentuk dua fase yang terpisah. Supernatan yang terbentuk dipindahkan ke tabung lain sambil dilewatkan pada $\mathrm{Na}_{2} \mathrm{SO}_{4}$ anhydrous. Ekstraksi dilakukan sebanyak 3 kali. Supernatan yang didapat dikumpulkan dalam satu tabung reaksi bertutup dan dievaporasi dengan gas $\mathrm{N}_{2}$ teknis sampai kering. Ekstrak kering yang didapat dilarutkan dengan $1 \mathrm{~mL}$ fase gerak. Setelah itu $20 \mu \mathrm{l}$ sampel tersebut diinjeksi ke HPLC.

Metode analisis sampel hati mengikuti Grebenstein dan Frank (2012). Sebanyak $200 \mathrm{mg}$ sampel dihancurkan dengan mortar dan dilarutkan dalam $2 \mathrm{~mL}$ asam askorbat (1\% dalam etanol), $900 \mu 1 \mathrm{H}_{2} \mathrm{O}$, dan $300 \mu \mathrm{KOH}$. Setelah itu dilakukan saponifikasi pada suhu $70{ }^{\circ} \mathrm{C}$ selama 30 menit. Sampel kemudian didinginkan. Setelah itu ditambahkan 25 $\mu 1$ BHT dalam etanol ( $1 \mathrm{mg}$ BHT/mL etanol), 1 mL $\mathrm{H}_{2} \mathrm{O}, 300$ $\mu \mathrm{l}$ asam asetat glasial, dan $2 \mathrm{~mL}$ heksan. Campuran tersebut dihomogenasi selama 1 menit dengan cara dikocok perlahan lalu vortex. Setelah terbentuk dua fase terpisah, maka supernatan diambil untuk dipindahkan ke tabung lain sambil dilewatkan pada $\mathrm{Na}_{2} \mathrm{SO}_{4}$ anhydrous. Ekstraksi dilakukan sebanyak 3 kali. Seluruh supernatan yang didapatkan lalu dievaporasi menggunakan gas $\mathrm{N}_{2}$ teknis. Setelah itu hasil ekstraksi dilarutkan dalam $100 \mu \mathrm{l}$ fase gerak. $20 \mu \mathrm{l}$ dari larutan tersebut kemudian diinjeksi ke dalam HPLC dengan panjang gelombang $290 \mathrm{~nm}$. Kromatogram yang terbaca dibandingkan dengan kromatogram standar $\alpha$-tokoferol. Jenis fase gerak, flow rate, panjang gelombang serta cara perhitungan sama dengan analisis $\alpha$-tokoferol pada MEMS.

\section{Analisis Bioavailabilitas $\alpha$-Tokoferol pada Minuman Emulsi Minyak Sawit}

Bioavailabilitas $\alpha$-tokoferol dihitung menggunakan Tocopherol Accumulation Factor atau TAF. Metode tersebut merupakan adaptasi dari metode yang digunakan untuk 
analisis bioavailabilitas $\beta$-karoten (Carrillo-Lopez dkk., 2010). Cara perhitungan TAF (Persamaan 2).

$\mathrm{TAF}=1 /$ (total intake $\alpha$-tokoferol selama replesi)(total akumulasi tokoferol hati replesi)

Total intake $\alpha$-tokoferol selama masa replesi didapatkan dari menghitung total intake ransum tiap hewan coba dikalikan kadar $\alpha$-tokoferol dalam ransum yang diberikan. Akumulasi tokoferol hati selama masa replesi merupakan selisih dari total tokoferol hati setelah replesi dikurangi total tokoferol hati setelah deplesi. Total tokoferol hati merupakan perkalian dari kadar tokoferol hati $(\mu \mathrm{g} / \mathrm{g})$ dengan berat organ hati (g).

Evaluasi bioavailabilitas $\alpha$-tokoferol dianalisis dengan TAF relatif. Penggunaan TAF sebagai metode analisis bioavailabilitas didasarkan dari pemahaman mengenai bioavailabilitas sebagai jumlah zat gizi yang diingesti dan berpotensi tersedia dalam bentuk yang bisa diabsorbsi oleh tubuh sehingga dapat dipertimbangkan sebagai rasio zat gizi yang berhasil diserap tubuh dengan zat gizi total yang dikonsumsi (Parada dan Aguilera, 2007).

\section{Analisis Statistik}

Rancangan perlakuan yang dilakukan pada analisis bioavailabilitas $\alpha$-tokoferol pada MEMS menggunakan rancangan acak lengkap (RAL) karena merupakan percobaan satu faktor dengan pengaruh lingkungan yang dikendalikan. Pembahasan dilakukan secara deskriptif dan dengan analisis sidik ragam satu arah $(\alpha=0,05)$ serta dilanjutkan dengan uji Duncan Multiple Range Test (DMRT) dengan menggunakan software SPSS 22 (IBM Statistics, US) guna menentukan perbedaan bioavailabilitas $\alpha$-tokoferol pada tiap kelompok. Selain itu, analisis tokoferol plasma dan TAF menggunakan t-test untuk mengetahui perbedaan antar kelompok uji.

\section{HASIL DAN PEMBAHASAN}

\section{Komposisi Minuman Emulsi Minyak Sawit}

Kadar $\alpha$-tokoferol olein yang digunakan untuk membuat MEMS sebesar $226,92 \mathrm{mg} / \mathrm{kg}$. Setelah diolah menjadi MEMS, kadar $\alpha$-tokoferol menjadi $192,63 \mathrm{mg} / \mathrm{kg}$. Komposisi MEMS yang dihasilkan tertera pada Tabel 1 . Penambahan EDTA pada formulasi yang digunakan mampu mempertahankan kandungan $\alpha$-tokoferol pada MEMS. EDTA merupakan antioksidan golongan metal chelator yang mampu menghambat oksidasi lipid pada emulsi oil-inwater, terutama yang memiliki $\mathrm{pH}$ antara 4-7 seperti MEMS, sehingga kestabilan $\alpha$-tokoferol dalam emulsi minyak sawit dapat dipertahankan.
Kadar lemak yang didapatkan sebesar 68,98\% dari total bahan. Hasil yang didapat ini lebih tinggi daripada kadar lemak pada MEMS yang diperoleh Meridian (2000), yaitu sebesar 56,27\%. Dengan konsentrasi tersebut, MEMS berpotensi memiliki bioavailabilitas $\alpha$-tokoferol yang baik.

Tabel 1. Komposisi minuman emulsi minyak sawit yang dihasilkan

\begin{tabular}{lr}
\hline Parameter & \multicolumn{1}{c}{ Nilai } \\
\hline Kadar protein $(\mathrm{g} / 100 \mathrm{~g})$ & 0,065 \\
Kadar lemak $(\mathrm{g} / 100 \mathrm{~g})$ & 68,98 \\
Kadar abu $(\mathrm{g} / 100 \mathrm{~g})$ & 0,015 \\
Kadar air $(\mathrm{g} / 100 \mathrm{~g})$ & 22,812 \\
Kadar karbohidrat $(\mathrm{g} / 100 \mathrm{~g})$ & 8,125 \\
$\alpha$-tokoferol $(\mathrm{mg} / \mathrm{kg})$ & 192,63 \\
\hline
\end{tabular}

Semakin tinggi jumlah lemak dalam sistem emulsi, makin banyak misel yang terbentuk di usus halus sehingga solubilitas meningkat dan mempermudah penyerapan $\alpha$-tokoferol (McClements dkk., 2016).

\section{Kondisi Hewan Percobaan Selama Pemeliharaan}

Cara pemantauan kondisi hewan percobaan dalam penelitian ini adalah melakukan pengamatan peningkatan berat badan. Peningkatan berat badan digunakan sebagai indikator tak langsung untuk melihat pengaruh pemberian jenis ransum terhadap perkembangan tikus. Pada awal masa adaptasi berat badan tikus sebesar 140-150 g dengan rata-rata berat badan sebesar $145,78 \mathrm{~g}$. Pada akhir masa adaptasi rata-rata berat badan tikus sebesar $164,23 \mathrm{~g}$ atau meningkat sebesar $18,45 \mathrm{~g}$. Di masa adaptasi semua tikus mendapat ransum yang sama, yakni ransum standar, dengan komposisi yang sama. Walaupun demikian, tidak semua tikus mengalami peningkatan berat badan. Hal ini mungkin terjadi karena beberapa tikus tersebut kurang mampu beradaptasi dengan lingkungan yang baru sehingga pola makan dan metabolismenya terganggu dan berakibat pada penurunan berat badan (Sogut dkk., 2015).

Pada akhir masa deplesi berat badan tikus sebesar 250,86 g pada kelompok kontrol dan 236,15 g pada kelompok deplesi. Bila dilihat dari kurva peningkatan berat badan (Gambar 2), kedua kelompok tersebut tidak berbeda nyata, namun berdasarkan pola peningkatannya terlihat perbedaan antara kedua kelompok. Peningkatan berat badan kelompok deplesi mulai dari pertengahan masa deplesi, yaitu hari ke 32, lebih sedikit daripada kelompok kontrol. Hal ini dapat disebabkan terjadinya perubahan metabolisme pada kelompok deplesi akibat penurunan cadangan vitamin di hati (Fernández- 
García dkk., 2012). Ketika tubuh dalam keadaan kekurangan vitamin E, maka terjadi peningkatan hormon CorticotropinReleasing-Factor (CRF) yang merupakan respon dari stres dan diregulasikan salah satunya oleh intake makanan. CRF mengaktivasi Hypothalamic-Pituitary-Adrenal (HPA), sistem saraf simpatik, dan sistem imun. Aktivitas HPA dapat mempengaruhi keseimbangan energi, terutama berkaitan dengan penurunan intake makanan dan pemanfaatan zat gizi. Intake vitamin $\mathrm{E}$ yang rendah mengaktivasi HPA dan mengakibatkan perubahan metabolisme corticosterone yang memicu stres metabolik sehingga berakibat pada penurunan berat badan. Tikus yang mendapat vitamin $\mathrm{E}$ dari intake makanan mengalami peningkatan berat badan lebih banyak daripada yang mendapat perlakuan deplesi dengan pemberian suplementasi $\alpha$-tokoferol dan tokotrienol. Salah satu dampak yang terlihat adalah terjadinya nekrosis otot sehingga berat badan menurun (Fahami dkk., 2005).

Pada masa replesi, kelompok kontrol (K) mengalami peningkatan berat badan dan total konsumsi ransum yang paling tinggi. Kelompok KN mengonsumsi ransum melebihi kelompok KP namun mengalami peningkatan berat badan paling sedikit jika dibandingkan kelompok lain. Kelompok KN tidak mengalami peningkatan berat badan yang konsisten dan terus mengalami penurunan berat badan setelah hari ketiga masa replesi. Hal ini dapat terjadi karena status defisiensi vitamin yang dialami kelompok KN. Semakin buruk status defisiensi semakin kecil pula kenaikan berat badan yang dialami (Ernst dkk., 2013). Peningkatan berat badan kelompok KP dan MEMS tidak berbeda nyata $(\alpha$ $=0,05)$. Sistem emulsi dapat secara efektif meningkatkan

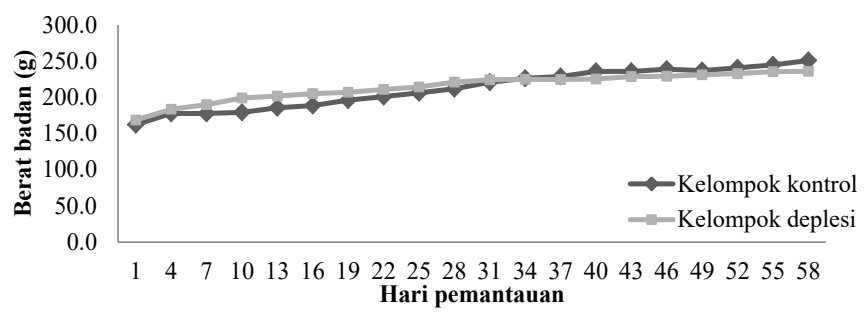

Gambar 2. Kurva peningkatan berat badan selama masa deplesi

Tabel 2. Rata-rata konsumsi ransum dan kenaikan berat badan di masa replesi

\begin{tabular}{lcc}
\hline Kelompok perlakuan & $\begin{array}{c}\text { Total Konsumsi } \\
\text { ransum }(\mathrm{g})\end{array}$ & $\begin{array}{c}\text { Kenaikan berat } \\
\text { badan }(\mathrm{g})\end{array}$ \\
\hline Kontrol $(\mathrm{K})$ & $262,43 \pm 20,26^{\mathrm{a}}$ & $23,00 \pm 9,45^{\mathrm{a}}$ \\
Kontrol positif $(\mathrm{KP})$ & $215,16 \pm 12,05^{\mathrm{c}}$ & $15,29 \pm 3,59^{\mathrm{ab}}$ \\
Kontrol negatif $(\mathrm{KN})$ & $225,83 \pm 20,13^{\mathrm{bc}}$ & $9,17 \pm 1,61^{\mathrm{b}}$ \\
Minuman emulsi $(\mathrm{MEMS})$ & $238,85 \pm 20,38^{\mathrm{b}}$ & $15,86 \pm 6,09^{\mathrm{ab}}$ \\
\hline
\end{tabular}

Keterangan: Angka yang diikuti huruf yang sama dinyatakan tidak berbeda nyata pada taraf uji $5 \%$ pertumbuhan tikus yang sebelumnya mengalami defisiensi vitamin $\mathrm{E}$ kronis. Hal ini ditunjukan oleh peningkatan berat badan kelompok KP dan MEMS yang tidak berbeda nyata dengan kelompok kontrol setelah masa replesi (Tabel 2).

\section{Tokoferol Plasma dan Hati}

Pada akhir masa adaptasi, rata-rata kadar tokoferol plasma hewan coba yang diterminasi sebesar $10,5 \mu \mathrm{g} / \mathrm{mL}$, sementara rata-rata kadar tokoferol hatinya sebesar 26,94 $\mu \mathrm{g} / \mathrm{g}$. Lalu pada akhir masa deplesi, kadar tokoferol plasma kelompok deplesi sebesar 0,81 $\mu \mathrm{g} / \mathrm{g}$ atau menurun $92,29 \%$ jika dibandingkan setelah adaptasi, sedangkan kadar tokoferol hati sebesar 3,52 $\mu \mathrm{g} / \mathrm{g}$ atau menurun 87,94\% jika dibandingkan setelah adaptasi. Setelah masa replesi, didapatkan kadar tokoferol plasma pada kelompok KP dan MEMS naik 58,46\% dan 43,36\% dari kadar tokoferol plasma setelah masa deplesi (Gambar 3A). Sementara itu, kadar tokoferol hati kelompok KP dan MEMS naik hingga mencapai 85,52\% dan 84,64\% dari kadar tokoferol hati setelah masa deplesi (Gambar 3B).

Dengan menggunakan uji lanjut Duncan Multiple Range Test (DMRT), tidak terdapat perbedaan nyata antara kadar tokoferol plasma kelompok KN, kelompok KP dan kelompok MEMS (Gambar 3A). Namun ketiga kelompok tersebut memiliki perbedaan nyata dengan kelompok kontrol (K). Hal ini dapat dikarenakan besarnya selisih rata-rata

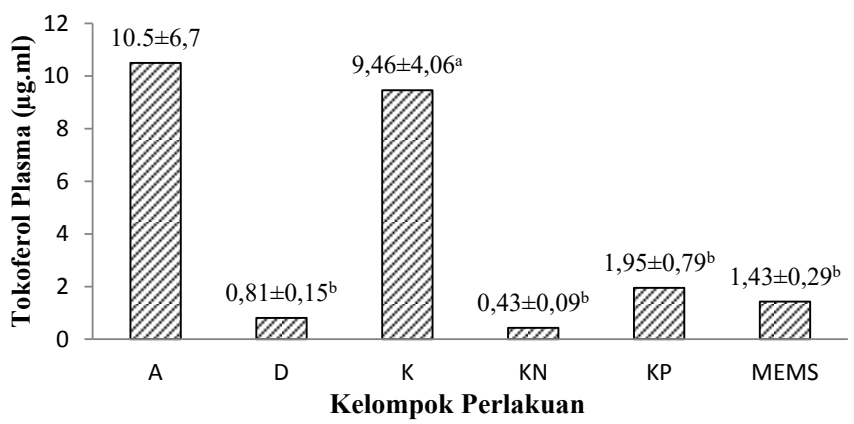

(A)

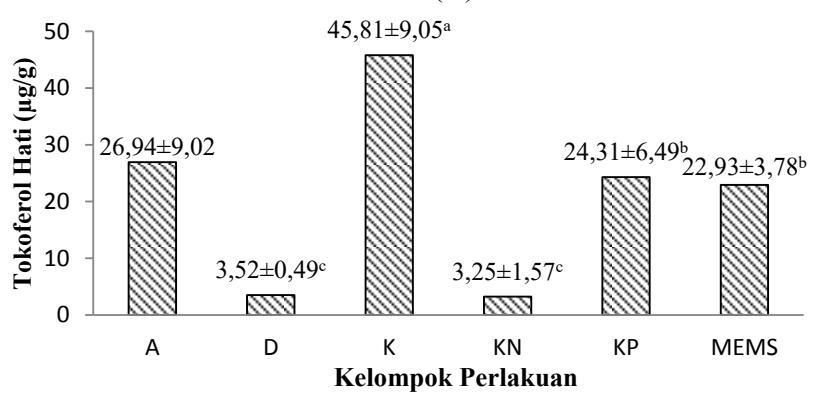

(B)

Keterangan: $\mathrm{A}=$ setelah masa adaptasi, $\mathrm{D}=$ setelah masa deplesi, $\mathrm{K}=$ Kontrol, KN = Kontrol Negatif, KP = Kontrol Positif, MEMS $=$ Minuman Emulsi Minyak Sawit. Angka yang diikuti huruf yang sama dinyatakan tidak berbeda nyata $(\alpha=0,05)$

Gambar 3. Kadar tokoferol plasma (A) dan tokoferol hati (B) setelah replesi 
Tabel 3. Analisis t-test tokoferol plasma tikus setelah masa replesi

\begin{tabular}{lcc}
\hline Kelompok & Sig. (2 tailed) & Keterangan \\
\hline MEMS banding KP & 0,162 & sama \\
MEMS banding KN & 0,000 & berbeda \\
\hline
\end{tabular}

Keterangan: $\mathrm{KN}=$ Kontrol Negatif, $\mathrm{KP}=$ Kontrol Positif, MEMS $=$ Minuman Emulsi Minyak Sawit. Signifikansi (2 tailed) $>0,05$ dinyatakan sama pada taraf uji 5\%

kadar tokoferol plasma kelompok $\mathrm{K}$ dengan kelompok lain sehingga mempengaruhi hasil uji lanjut DMRT. Oleh karena itu, dilakukan juga uji lanjut t-test untuk mengetahui perbedaan antara dua kelompok, yaitu kelompok MEMS banding KP, dan kelompok MEMS banding KN. Melalui uji lanjut t-test didapatkan bahwa tidak terdapat perbedaan antara kelompok MEMS dengan kelompok KP, namun kelompok MEMS berbeda dengan kelompok KN (Tabel 3).

Pada analisis kadar tokoferol hati (Gambar 3B), ditemukan bahwa kadar tokoferol hati kelompok MEMS berbeda nyata dengan kelompok KN dan tidak berbeda nyata dengan kelompok KP. Kelompok KP dan MEMS juga berbeda nyata dengan kelompok kontrol. Oleh karena itu, dapat dinyatakan bahwa MEMS secara signifikan meningkatkan tokoferol plasma dan hati setelah masa replesi.

Kadar tokoferol salah satunya diatur oleh $\alpha$-Tocopherol Transfer Protein ( $\alpha$-TTP). $\alpha$-TTP merupakan protein pengikat $\alpha$-tokoferol yang memfasilitasi transportasi $\alpha$-tokoferol ke lipoprotein di plasma (Lim dan Traber, 2007). Keberadaan $\alpha$-TTP dipengaruhi oleh intake dan status vitamin E. Kadar $\alpha$-TTP pada hati lebih tinggi daripada plasma, baik pada pemberian $\alpha$-tokoferol dosis rendah maupun tinggi (Bella dkk., 2006). Semakin tinggi kadar $\alpha$-TTP, semakin tinggi pula kadar $\alpha$-tokoferol di suatu jaringan. Peningkatan kadar tokoferol plasma tidak sebesar kadar tokoferol hati. Kondisi tersebut dapat dikarenakan perbedaan kadar $\alpha$-TTP di hati dan plasma sehingga mempengaruhi peningkatan kadar tokoferol. Hasil yang didapat sesuai dengan penelitian Bella dkk. (2006) yang menyatakan bahwa dengan suplementasi $\alpha$-tokoferol dosis rendah maupun dosis tinggi, respon peningkatan tokoferol plasma tidak setinggi tokoferol hati. Hal itu mungkin terjadi karena peningkatan tokoferol plasma dihambat oleh peningkatan marginal tokoferol hati atau kemampuan lipoprotein yang disekresi hati untuk menerima dan membawa jumlah $\alpha$-tokoferol ke sistem sirkulasi.

\section{Bioavailabilitas $\alpha$-Tokoferol pada Minuman Emulsi Minyak Sawit}

Nilai TAF untuk kelompok KP sebesar 1/45,61 sedangkan nilai TAF untuk kelompok MEMS sebesar 1/37,61 (Tabel 4). Hal ini berarti untuk menghasilkan $1 \mu \mathrm{g}$ tokoferol
Tabel 4. Tocopherol Accumulation Factor (TAF) kontrol positif dan minuman emulsi

\begin{tabular}{cccc}
\hline Kelompok & $\begin{array}{c}\text { Akumulasi } \\
\text { tokoferol hati }(\mu \mathrm{g})\end{array}$ & $\begin{array}{c}\text { Total intake } \\
\alpha \text {-tokoferol }(\mu \mathrm{g})\end{array}$ & TAF \\
\hline KP & $200,94 \pm 95,89$ & $6235,90 \pm 590,74$ & $1 / 37,61 \pm 18,21^{\text {a }}$ \\
MEMS & $178,00 \pm 55,37$ & $7263,90 \pm 606,23$ & $1 / 45,61 \pm 17,92^{\text {a }}$ \\
\hline
\end{tabular}

Keterangan: $\mathrm{TAF}=1 /$ (total intake $\alpha$-tokoferol/akumulasi tokoferol hati). Angka yang diikuti huruf yang sama dinyatakan tidak berbeda nyata $(\alpha=0,05)$

hati dibutuhkan 37,61 $\mu \mathrm{g}$ a-tokoferol murni atau 45,61 $\mu \mathrm{g} \alpha$-tokoferol dari MEMS. TAF relatif MEMS terhadap $\alpha$-tokoferol murni adalah sebesar $82,46 \%$.

Bioavailabilitas $\alpha$-tokoferol dipengaruhi oleh keberadaan lemak. $\alpha$-tokoferol membutuhkan kilomikron sebagai media transportasi dalam tubuh (Gee, 2011). Kilomikron tersebut membawa $\alpha$-tokoferol masuk ke dalam sistem limfatik dalam bentuk droplet lemak. Droplet lemak akan dihidrolisis oleh enzim lipase dan membentuk misel (McClements dkk., 2016). Absorbsi $\alpha$-tokoferol dalam oil-in-water emulsion lebih tinggi pada emulsi yang mengandung Long Chain Triacylglycerol (LCT) daripada yang mengandung Medium Chain Triacylglycerol atau MCT (Yang dan McClements, 2013). Hal ini terjadi karena minyak dengan LCT meningkatkan kemampuan kapasitas solubilitas misel untuk mengakomodasi molekul vitamin $\mathrm{E}$ yang bersifat lipofilik. Minyak Sawit kaya akan asam oleat yang merupakan asam lemak rantai panjang atau Long Chain Fatty Acids (LCFA). Ketika sampai di usus halus, LCFA akan diubah menjadi LCT. Meskipun penyerapan LCT lebih sulit daripada MCT tapi bioavailabilitasnya lebih tinggi daripada MCT (Takeuchi dkk., 2008).

Total tokoferol hati didapatkan dari kandungan tokoferol hati dikali berat organ hati. Kadar total tokoferol hati meningkat cukup tinggi, yaitu sebesar 85,82\% untuk kelompok MEMS dan 85,52\% untuk kelompok KP (Gambar 4A). Jika dibandingkan dengan KP, MEMS mampu meningkatkan total tokoferol hati sebesar 90,10\% dari $\alpha$-tokoferol murni. Hasil yang didapatkan tersebut selaras dengan peningkatan kadar tokoferol plasma, meskipun hasil peningkatan tokoferol plasma tidak setinggi tokoferol hati. Hal ini mungkin terjadi karena dua kelompok tersebut dalam kondisi defisiensi vitamin E sehingga $\alpha$-tokoferol yang diberikan langsung digunakan dan disimpan sebagai cadangan vitamin dalam hati (Bella dkk., 2006).

Total tokoferol hati kelompok MEMS tidak berbeda nyata dengan kelompok KP namun berbeda nyata dengan kelompok kontrol dan kelompok KN. Total tokoferol hati kelompok MEMS pada akhir masa replesi mencapai 58,16\% kelompok kontrol, sementara total tokoferol hati kelompok KP sebesar 64,19\% kelompok kontrol. Hal ini berarti terjadi 
peningkatan tokoferol hati yang signifikan selama 14 hari masa replesi. Kontribusi MEMS dalam mengembalikan tokoferol hati pada akhir masa replesi mencapai 88,54\% $\alpha$-tokoferol murni (Gambar 4B). Kontribusi tersebut merupakan rasio dari selisih total tokoferol hati kelompok MEMS atau kelompok KP dengan kelompok KN dibandingkan dengan total tokoferol hati kelompok kontrol.

MEMS memiliki kemampuan mengembalikan cadangan tokoferol hati mendekati $\alpha$-tokoferol murni sehingga dapat memperbaiki status vitamin E. Salah satu yang mengindikasikan perbaikan status vitamin $\mathrm{E}$ adalah terjadi peningkatan berat badan. Pada masa replesi, rata-rata peningkatan berat badan kelompok MEMS sebesar 1,13 g/ hari dengan konsumsi $\alpha$-tokoferol rata-rata $511 \mu \mathrm{g} /$ hari. Hasil yang didapatkan ini selaras dengan Ernst dkk. (2013) yang menyebutkan bahwa tikus dengan defisiensi vitamin E yang diberikan suplementasi sebesar $500 \mu \mathrm{g} / \mathrm{g}$ mengalami perbaikan status vitamin $\mathrm{E}$, ditunjukan salah satunya dengan peningkatan berat badan minimum sebesar $0,1 \mathrm{~g} / \mathrm{hari}$. Keberadaan $\alpha$-tokoferol pada MEMS lebih mudah diserap tubuh karena adanya peran minyak sawit sebagai carrier. Seperti bentuk vitamin $\mathrm{E}$ yang lain, $\alpha$-tokoferol juga memiliki kelarutan

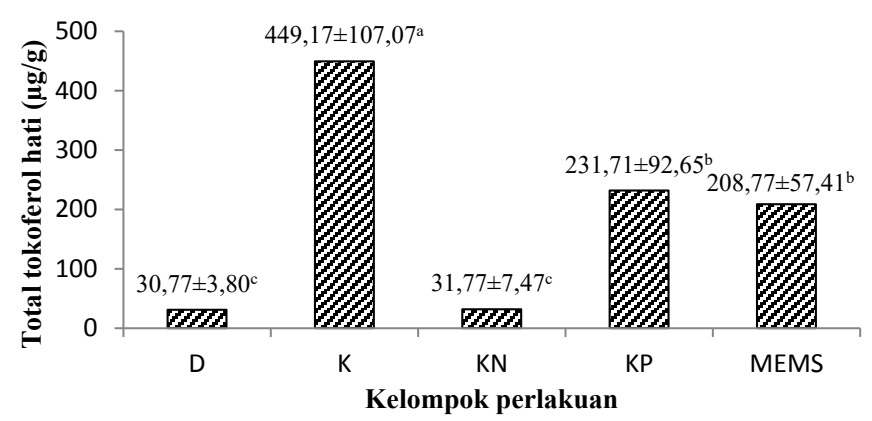

(A)

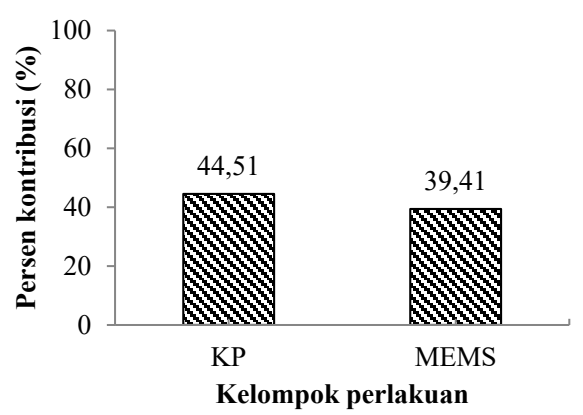

(B)

Keterangan: $\mathrm{D}=$ Setelah masa deplesi, $\mathrm{K}=$ Kontrol, $\mathrm{KN}=$ Kontrol Negatif, $\mathrm{KP}=$ Kontrol Positif, MEMS $=$ Minuman Emulsi Minyak Sawit. Angka yang diikuti huruf yang sama dinyatakan tidak berbeda nyata $(\alpha=0,05)$

Gambar 4. Total tokoferol hati (A) dan kontribusi $\alpha$-tokoferol murni dan minuman emulsi dalam mengembalikan tokoferol hati (B) tinggi dalam lemak. Lemak mempengaruhi penyerapan vitamin E melalui beberapa mekanisme. Pertama, lemak dapat memfasilitasi pelepasan vitamin E dari matriks pangan melalui pembentukan fase hidrofobik untuk melarutkan lemak. Kedua, lemak menstimulasi sekresi empedu dan pembentukan misel sehingga meningkatkan proporsi vitamin E dalam misel yang siap diabsorbsi. Ketiga, produk hasil digesti lipid seperti asam lemak, monogliserida, dan fosfolipid merupakan komponen misel yang bila konsentrasinya makin tinggi maka makin banyak pula misel yang dapat terbentuk dan dapat melarutkan vitamin E. Selain itu, melalui sintesis kilomikron lemak dapat meningkatkan transport vitamin $\mathrm{E}$ diluar enterosit (Borel dkk., 2013). Faktor-faktor itulah yang memungkinkan $\alpha$-tokoferol pada minuman emulsi minyak sawit dapat memiliki bioavailabilitas yang baik.

\section{KESIMPULAN}

Kandungan $\alpha$-tokoferol Minuman Emulsi Minyak Sawit (MEMS) sebesar 192,63 mg/kg. Alfa-tokoferol pada MEMS mampu diserap, disimpan, dan digunakan dalam tubuh tikus yang sebelumnya mengalami defisiensi vitamin E lalu mendapat perlakuan replesi. Bioavailabilitas relatif MEMS terhadap $\alpha$-tokoferol murni sebesar $82,46 \%$. Kontribusi MEMS dalam mengembalikan cadangan tokoferol hati sebesar 39,41\%, atau sebesar 88,54\% $\alpha$-tokoferol murni. Oleh karena itu dapat disimpulkan bahwa MEMS memiliki bioavailabilitas $\alpha$-tokoferol dan nilai gizi yang baik.

\section{UCAPAN TERIMA KASIH}

Penulis menyampaikan terima kasih kepada Lembaga Pengelola Dana Pendidikan (LPDP) yang telah memberikan dana bantuan penelitian melalui Beasiswa Pendidikan Indonesia dan Direktorat Pendidikan Tinggi atas dana bantuan penelitian melalui Hibah Kompetensi 2 tahun 2015 atas nama Prof. Dr. Ir. Tien R. Muchtadi, M.S. untuk rangkaian penelitian Prospek Industrialisasi Produk Hilir Minyak Kelapa Sawit.

\section{DAFTAR PUSTAKA}

Association of Official Analytical Chemist (AOAC). (2005). Official Methods of Analysis (18 ${ }^{\text {th }}$ edition). Association of Official Analytical Chemistry. Published by the Association of Official Analytical Chemist. New York, USA.

Association of Official Analytical Chemist (AOAC). (2012). Official Methods of Analysis (19 ${ }^{\text {th }}$ edition). Association of Official Analytical Chemistry. Published by the Association of Official Analytical Chemist. New York, USA. 
Badan Standarisasi Nasional (BSN). (2006). Standar Nasional Indonesia (SNI) nomor 01-2354.3-2006. Published by Badan Standarisasi Nasional. Jakarta, Indonesia

Ball, G.F.M. (2006). Vitamins in Foods: Analysis, Bioavailability, and Stability. Taylor and Francis Group, Boca Raton

Bella, D.L., Schock, B.C., Lim, Y., Leonard, S.W., Berry, C., Cross, C.E., Traber, M.G. (2006). Regulation of the alpha-tocopherol transfer protein in mice: lack of response to dietary vitamin $\mathrm{E}$ or oxidative stress. Lipids 41, 105-12.

Borel, P., Preveraud, D., Desmarchelier, C. (2013). Bioavailability of vitamin $\mathrm{E}$ in humans: An update. Nutrition Review 71, 319-331.

Carrillo-Lopez, A., Yahia, E.M., Ramirez-Padilla, G.K. (2010). Bioconversion of carotenoids in five fruits and vegetables to vitamin a measured by retinol accumulation in rat livers. American Journal of Agricultural and Biological Sciences 5(2): 215-221.

Devaraj, S., Tang, R., Adams-Huet, B., Harris, A., Seenivasan, T., de Lemos, J.A., Jialal, I., (2007). Effect of highdose alpha-tocopherol supplementation on biomarkers of oxidative stress and inflammation and carotid atherosclerosis in patients with coronary artery disease. American Journal of Clinical Nutrition 86(5): 13921398.

Domitrovic, R., Tota, M., Milin, C. (2008). Differential Effect of High Dietary Iron on $\alpha$-Tocopherol and Retinol Levels in The Liver and Serum of Mice Fed Olive Oiland Corn Oil-Enriched Diets. Nutrition Research 28(4): 263-269.

Ernst, I.M.A., Pallauf, K., Bendall, J.K., Paulsen, L., Nikolai, S., Huebbe, P., Roeder, T., Rimbach, G. (2013). Vitamin E supplementation and lifespan in model organisms. Aging Research Review 12: 365-375.

Fahami, N.A.M, Ismail, N.M, Khalid, K.B.A. (2005). Effects of Vitamin $\mathrm{E}$ on Food Intake and Body Weight in Rats Exposed to Restraints Stress. Medical Journal of Islamic World Academy of Science 15(2): 81-86.

Fernández-García, E., Carvajal-Lérida, I., Jarén-Galán, M., Garrido-Fernández, J., Pérez-Gálvez, A., HorneroMéndez, D. (2012). Carotenoids bioavailability from foods: From plant pigments to efficient biological activities. Food Research International 46, 438-450.

Gagne, A., Wei, S.Q., Fraser, W.D., Julien, P. (2009). Absorption, Transport, and Bioavailability of Vitamin E and its Role in Pregnant Women. Journal of Obstetetry and Gynaecology Canada 31, 210-217.

Gee, P.T. (2011). Unleashing the untold and misunderstood observations on vitamin e. Genes Nutrition 6, 5-16.

Grebenstein, N., Frank, J. (2012). Rapid baselineseparation of all eight tocopherols and tocotrienols by reversed-phase liquid-chromatography with a solid-core pentafluorophenyl column and their sensitive quantification in plasma and liver. Journal of Chromatography A 1243: 39-46.

Hatanaka, J., Chikamori, H., Sato, H., Uchida, S., Debari, K., Onoue, S., Yamada, S. (2010). Physicochemical and pharmacological characterization of $\alpha$-tocopherolloaded nano-emulsion system. International Journal of Pharmacheutics 396, 188-193.

Li, C., Li, R.W., Elsasser, T.H. (2010). Gene Regulation and Systems Biology Alpha-Tocopherol Modulates Transcriptional Activities that Affect Essential Biological Processes in Bovine Cells Gene Regulation and System Biology 4: 109-124

Lim, Y., Traber, M.G. (2007). Alpha-Tocopherol Transfer Protein ( $\alpha$-TTP): Insights from Alpha-Tocopherol Transfer Protein Knockout Mice. Nutrition Research and Practice 1, 247-253.

Mancini, A., Imperlini, E., Nigro, E., Montagnese, C., Daniele, A., Orru, S., Buono, P. (2015). Biological and nutritional properties of palm oil and palmitic acid: Effects on health. Molecules 20, 17339-17361.

McClements, D.J., Saliva-Trujillo, L., Zhang, R., Zhang, Z., Zou, L., Yao, M., Xiao, H. (2016). Boosting the bioavailability of hydrophobic nutrients, vitamins, and nutraceuticals in natural products using excipient emulsions. Food Research International 88, 140-152.

Meridian. Y.A. (2000). Kajian Ketersediaan Hayati $\beta$-Karoten Minuman Emulsi Karoten Minyak Sawit dalam Hati dan Plasma Tikus (Rattus norvegicus). Skripsi. Fakultas Teknologi Pertanian. Institut Pertanian Bogor.

Parada, J., Aguilera, J.M. (2007). Food microstructure affects the bioavailability of several nutrients. Journal of Food Science 72, 21-32.

Sogut, E., Kad, H., Karayakal, M., Mertoglu, C. (2015). The association of plasma vitamin $\mathrm{A}$ and $\mathrm{E}$ levels with coronary collateral circulation. Atherosclerosis 239, 547-551.

Surfiana. (2002). Formulasi Minuman Emulsi Kaya $\beta$-karoten dari Minyak Sawit Merah. Tesis. Fakultas Teknologi Pertanian. Institut Pertanian Bogor. 
Takeuchi, H., Sekine, S., Kojima, K., Aoyama, T. (2008). The application of medium-chain fatty acids: edible oil with a suppressing effect on body fat accumulation 382. Asia Pacific Journal of Clinical Nutrition 17(1), 320-323.
Yang, Y., McClements, D.J.(2013). Vitamin E bioaccessibility: Influence of carrier oil type on digestion and release of emulsified $\alpha$-tocopherol acetate. Food Chemistry 141, 473-481. 